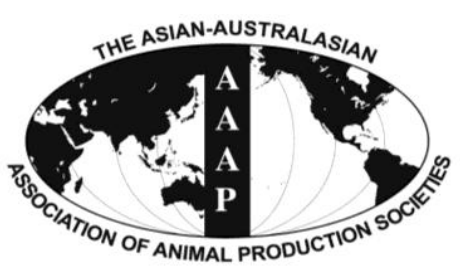

Open Access

Asian Australas. J. Anim. Sci.

Vol. 28, No. $10: 1442-1448$ October 2015

http://dx.doi.org/10.5713/ajas.13.0834

www.ajas.info

pISSN 1011-2367 elSSN 1976-5517

\title{
Molecular Weight, Protein Binding Affinity and Methane Mitigation of Condensed Tannins from Mangosteen-peel (Garcinia mangostana L)
}

\author{
P. Paengkoum*, T. Phonmun' ${ }^{1}$, J. B. Liang ${ }^{2}$, X. D. Huang ${ }^{2}$, H. Y. Tan ${ }^{3}$, and M. F. Jahromi ${ }^{2}$ \\ Institute of Agricultural Technology, Suranaree University of Technology, Muang, Nakhon Ratchasima 30000, Thailand
}

\begin{abstract}
The objectives of this study were to determine the molecular weight of condensed tannins (CT) extracted from mangosteen (Garcinia mangostana L) peel, its protein binding affinity and effects on fermentation parameters including total gas, methane $\left(\mathrm{CH}_{4}\right)$ and volatile fatty acids (VFA) production. The average molecular weight $\left(\mathrm{M}_{\mathrm{w}}\right)$ of the purified CT was $2,081 \mathrm{Da}$ with a protein binding affinity of 0.69 (the amount needed to bind half the maximum bovine serum albumin). In vitro gas production declined by $0.409,0.121$, and 0.311 , respectively, while $\mathrm{CH}_{4}$ production decreased by $0.211,0.353$, and 0.549 , respectively, with addition of 10 , 20 , and $30 \mathrm{mg} \mathrm{CT} / 500 \mathrm{mg}$ dry matter (DM) compared to the control $(\mathrm{p}<0.05)$. The effects of CT from mangosteen-peel on in vitro DM degradability (IVDMD) and in vitro $\mathrm{N}$ degradability was negative and linear $(\mathrm{p}<0.01)$. Total VFA, concentrations of acetic, propionic, butyric and isovaleric acids decreased linearly with increasing amount of CT. The aforementioned results show that protein binding affinity of CT from mangosteen-peel is lower than those reported for Leucaena forages, however, the former has stronger negative effect on IVDMD. Therefore, the use of mangosteen-peel as protein source and $\mathrm{CH}_{4}$ mitigating agent in ruminant feed requires further investigations. (Key Words: Condensed Tannins, Mangosteen-peel, Methane Production, Molecular Weight, Protein Binding Affinity)
\end{abstract}

\section{INTRODUCTION}

Microbial fermentation of feedstuff in the rumen produces volatile fatty acids (VFA) and microbial protein to provide the bulk of the energy and protein required by the host animal. Methane $\left(\mathrm{CH}_{4}\right)$ is produced during the fermentation process and represents 0.020 to 0.120 of the dietary gross energy loss (Johnson and Johnson, 1995). Methanogenic organisms use the $\mathrm{H}_{2}$ produced during carbohydrate fermentation to reduce $\mathrm{CO}_{2}$ to $\mathrm{CH}_{4}$, therefore, compounds that inhibit the activity of methanogens are likely to reduce ruminal $\mathrm{CH}_{4}$ production, which has been implicated as a source of greenhouse gases affecting global

\footnotetext{
* Corresponding Author: P. Paengkoum. Tel: +66-4422-4575, Fax: +66-4422-4150, E-mail: pramote@ sut.ac.th

${ }^{1}$ King Mongkut Institute of Technology Ladkrabang Chumphon Campus, Pathio, Chumphon 86160, Thailand.

${ }^{2}$ Institute of Tropical Agriculture, Universiti Putra Malaysia, 43400 UPM Serdang, Malaysia.

${ }^{3}$ School of Public Health, Lanzhou University, Lanzhou 730000, China.

Submitted Dec. 20, 2013; Revised Feb. 26, 2014; Accepted Apr. 11, 2015
}

warming and climate change. Because $\mathrm{CH}_{4}$ production has a negative correlation with energy exploitation in ruminants, there have been considerable efforts to reduce its production to enhance VFA and microbial mass yields.

Tannins are polyphenols found in many plants (Terril et al., 1992). They can be subdivided into hydrolysable tannins (HT) and condensed tannins (CT). Condensed tannins usually have higher molecular weights $(1,000$ to 20,000 Da) than HT (500 to 3,000 Da) (Frutos et al., 2004). One of the main features of CT is its affinity to bind and precipitate proteins which are affected by type, molecular mass, structure of tannins (Huang et al., 2011b) and quality of fiber (Tiemann et al., 2008a). Research has suggested that CT suppresses methanogenesis by reducing methanogen population in the rumen directly or via reduction of protozoa population (McAllister et al., 1994; Ngamsaeng et al., 2006; Tan et al., 2011) and decreased $\mathrm{NH}_{3}-\mathrm{N}$ (Makkar et al., 1997; Sahoo et al., 2010).

Mangosteen (Garcinia mangostana) is a common indigenous fruit in the South-east Asian countries, including Thailand, and its peel (a byproduct from the fruit processing industry) contains a high crude tannins content $(0.070$ to 
0.150 of dry matter $[\mathrm{DM}])$ and crude protein (CP; 0.083 to 0.215 of DM) (Ngamsaeng et al., 2006; Suchitra and Wanapat, 2008). Because of its high CP content, mangosteen-peel could serve as a feed ingredient for ruminant animals. However, the presence of CT may affect the availability of the protein to the animals as it has been reported that $\mathrm{CT}$, particularly high molecular weight $\mathrm{CT}$ exhibits strong protein binding affinity and inhibits $\mathrm{CH}_{4}$ production (Huang et al., 2011a,b). The objectives of this study were to determine the concentration and molecular weight of CT of mangosteen peel, and examine the effects of the CT from mangosteen-peel on protein binding affinity, $\mathrm{CH}_{4}$ production and other fermentation parameters in vitro.

\section{MATERIALS AND METHODS}

\section{Extraction and purification of condensed tannins}

Pre-dry manogsteen-peel powder sold commercially in Thailand was used for this study. The manogesteen-peel producers normally collect the raw material (a wasteproduct) from local fruit processing plants from different locations which in turn purchased the mangosteen fruits from different fruit orchards. Condensed tannins were extracted from the above mentioned mangosteen-peel using aqueous acetone/diethyl ether following the protocol of Terrill et al. (1992) and purified (Terrill et al., 1990) with a $40 \mathrm{~cm} \times 16 \mathrm{~mm}$ id 16 column (GE Healthcare Bio-Science AB, Uppsala, Sweden) packed with Sephadex LH-20 (GE Healthcare Bio-Science AB, Sweden) as described by Huang et al. (2010). Low molecular weight tannins and other polyphenols were eluted with $400 \mathrm{~mL} / \mathrm{L}$ methanol and the CT with $800 \mathrm{~mL} / \mathrm{L}$ aqueous acetone. After evaporating traces of aqueous acetone using Buchi rotary evaporator (Buchi Labortechnic, Flawil, Switzerland), the purified CT were lyophilized and stored at $4{ }^{\circ} \mathrm{C}$ in the dark for molecular weight, protein binding affinity and in vitro rumen fermentation studies.

\section{Molecular weight determination}

Molecular weight of the purified CT was determined using Gel Permeation chromatography (Waters, Milford, DE, USA) with columns ( $25 \mathrm{mM}$ borate, $25 \mathrm{mM}$ potassium chloride, $\mathrm{pH}$ 8.5. Column bed dimensions: $16 \mathrm{~mm}$ diameter $\times \sim 16 \mathrm{~cm}$. Flow rate: $\sim 3 \mathrm{~mL} / \mathrm{h}) 0.5$, HR 1 , and HR 2 , for molecular mass ranges of 0 to $1,000,100$ to 5,000 , and 5,000 to $20,000 \mathrm{Da}$, respectively) connected in series as previously described by Huang et al (2010). Purified CT was dissolved in tetrahydrofuran which was also used as solvent at $1 \mathrm{~mL} / \mathrm{min}\left(25^{\circ} \mathrm{C}\right)$. Relative molecular weights were calculated after calibration with polystyrene (molecular weight standards) in the range of 162 to 22,000 Da. Weight-average molecular weights $\left(M_{\mathrm{w}}\right)$ were used to represent relative molecular weights of the purified CTs.
Polydispersity index (PDI), is a measure of the distribution of molecular mass in a given polymer sample in organic chemistry which indicates the distribution of individual molecular mass in a batch of polymers. The PDI was calculated as $M_{\mathrm{w}}$ divided by the number average molecular weight $\left(M_{\mathrm{n}}\right)$ : PDI $=M_{\mathrm{w}} / M_{\mathrm{n}}$. Degree of polymerization was also estimated on the basis of a constituent proanthocyanidin peracetate $\mathrm{M}_{\mathrm{w}}$ of approximately 500 (Williams et al., 1983).

\section{Protein binding affinity of condensed tannins}

Protein binding affinity of the purified CT was determined using protein precipitation assay with bovine serum albumin (BSA) to determine the relative capacities of the extracted CT to bind protein (Makkar et al., 1987) with minor modification (Huang et al., 2010). Different concentrations of BSA, from 0 to $1.2 \mathrm{mg} / \mathrm{mL}$ were used to generate the standard curve. The $0.5 \mathrm{~mL}$ of BSA buffer (1 $\mathrm{mg} / \mathrm{mL}$ of BSA dissolved in $0.2 \mathrm{M}$ acetate buffer [pH 5.0] containing $0.17 \mathrm{M} \mathrm{NaCl}$ ) and $50 \mathrm{~mL} / \mathrm{L}$ methanol were added to the $\mathrm{CT}$ at concentrations of $0,0.2,0.4,0.6,0.8,1.0$, 1.2 , and $1.6 \mathrm{mg}$, vortexed at room temperature for $15 \mathrm{~min}$ and centrifuged at 5,000 $\times g$ for $20 \mathrm{~min}$. The supernatant was discarded and the unbound protein was removed by washing with $1.5 \mathrm{~mL}$ of $0.2 \mathrm{M}$ acetate buffer, centrifuged at $5,000 \mathrm{~g}$ for $20 \mathrm{~min}$, dried in the oven at $100^{\circ} \mathrm{C}$ overnight. The hydrolysis was carried out by using $13.5 \mathrm{M} \mathrm{NaOH}$ in the oven at $120^{\circ} \mathrm{C}$ for $20 \mathrm{~min}$. The tubes were cooled after 1 $\mathrm{mL}$ acetic acid was gently added and an aliquot of $0.1 \mathrm{~mL}$ was added to $1 \mathrm{~mL}$ of ninhydrin solution. Then incubated in a $100^{\circ} \mathrm{C}$ water bath for $20 \mathrm{~min}$ and $5 \mathrm{~mL}$ of deionized water added after the tube was cooled. The absorbance was recorded at $570 \mathrm{~nm}$ after vortexing. Equation for protein binding data was analyzed using a non-linear regression procedure. The curve for CT was fitted in a sigmoid curve: $\mathrm{Y}=a /\left(1+\mathrm{b} \times \exp ^{(-c x)}\right)$, where $\mathrm{Y}=\mathrm{mg}$ of BSA precipitated, $X$ $=\mathrm{mg}$ of CT incubated. Protein binding affinity of CT was expressed as b-value, which represents the amount of CT used to bind half of the maximum BSA.

\section{In vitro fermentation parameters}

Gas production was determined according to Menke and Steingass (1988). Rumen fluid was collected from two rumen fistulated cattle (fed a 0.4 concentrate: 0.6 forage diet) prior to the morning meal. The rumen fluid was immediately transported to the laboratory and homogenized with a kitchen-blender, filtered through four layers of cheese-cloth and continuously purged with $\mathrm{CO}_{2}$. The wellmixed and $\mathrm{CO}_{2}$-flushed rumen fluid was added to the buffered rumen fluid solution, which was maintained in a water bath at $39^{\circ} \mathrm{C}$. Standard hay (University of Hohenheim, Stuttgart, Germany) with a predictable gas production of $49.61 \mathrm{~mL} / \mathrm{g} \mathrm{DM}$ used as a standard to calibrate the in vitro 
gas production system. About $500 \mathrm{mg}$ of Panicum maximum substrate with 0 (control), 10,20 , and $30 \mathrm{mg}$ CT/500 mg DM were incubated for $24 \mathrm{~h}$ with $40 \mathrm{~mL}$ buffered rumen fluid under continuous $\mathrm{CO}_{2}$ reflux in 100 $\mathrm{mL}$ calibrated glass syringes (Haberle Labortechnik, Lonsee-Ettlenschieb, Germany) in a water bath maintained at $39^{\circ} \mathrm{C}$. Samples were incubated in triplicate together with three syringes containing only incubation medium (blank).

Six syringes for each treatment were used for total gas, $\mathrm{CH}_{4}, \mathrm{CO}_{2}$, and $\mathrm{H}_{2}$ production. The volume of gas produced was determined by subtracting the volume of gas displaced in the headspace of the syringes with the initial volume (prior to incubation). The concentrations of $\mathrm{CH}_{4}, \mathrm{CO}_{2}$, and $\mathrm{H}_{2}$ in the headspace gas phase of syringes were determined by injecting $500 \mu \mathrm{L}$ of the gas into the gas chromatograph (Agilent 6890 Series Gas Chromatograph, Wilmington, DE, USA) equipped with thermal conductivity detector. Separation was achieved using a HP-Plot Q column (30 $\mathrm{m} \times 0.53 \mathrm{~mm} \times 40 \mu \mathrm{m}$ ) (Agilent Technologies, Wilmington, DE, USA) with nitrogen (MOX, Kuala Lumpur, Malaysia) as the carrier gas at the flow rate of $3.5 \mathrm{~mL} / \mathrm{min}$. An isothermal oven temperature of $50^{\circ} \mathrm{C}$ was adopted in the separation. The retention times for $\mathrm{CH}_{4}, \mathrm{CO}_{2}$, and $\mathrm{H}_{2}$ were determined using a mixtures of gases prepared by Scott Specialty Gases (Supelco, Bellefonte, PA, USA) which contain $10 \mathrm{~mL} / \mathrm{L} \mathrm{CH}_{4}, \mathrm{CO}_{2}, \mathrm{O}_{2}$, and $\mathrm{H}_{2}$. The calibration of standards for the gases were carried out using pure $\mathrm{CH}_{4}$ $(990 \mathrm{~mL} / \mathrm{L}), \mathrm{CO}_{2}(990 \mathrm{~mL} / \mathrm{L})$ (MOX, Kuala Lumpur, Malaysia) and $\mathrm{H}_{2}(10 \mathrm{~mL} / \mathrm{L})$ respectively.

For calibration of the gas chromatograph, the models of non-linear gas production were obtained by fitting data of cumulative gas production to the exponential equation described as $p=b\left[1-\mathrm{e}^{-c(t)}\right]$ (Ørskov and McDonald, 1979); where $p$ represents the cumulative gas production at time $t$, $c$ is the rate of gas production (per $\mathrm{h}$ ), and $b$ equals the potential gas production. To do this, the amount of cumulative gas produced at $2,4,8,10,12$, and $24 \mathrm{~h}$ incubation were determined.

After $24 \mathrm{~h}$ of incubation, the contents of three syringes were centrifuged at $3,500 \times \mathrm{g}$ for $15 \mathrm{~min}$ and the pellet was used for in vitro DM degradability (IVDMD) and the supernatant for VFA analysis. Another set of three syringes were used for the determination of in vitro nitrogen degradability (IVND). The IVDMD and IVND were determined using methods of Jones et al. (2000) modified from Tilley and Terry (1963) by comparing the weight of residues before and after drying in oven at $60^{\circ} \mathrm{C}$ for IVDMD and residues from the other set of incubation syringes for IVND determination were washed with distilled water, centrifuged at $3,000 \times \mathrm{g}$ for $10 \mathrm{~min}$ at $25^{\circ} \mathrm{C}$ and incubated at $39^{\circ} \mathrm{C}$ for $24 \mathrm{~h}$ in $40 \mathrm{~mL}$ of acid pepsin. Residues were then dried at $45^{\circ} \mathrm{C}$ for $72 \mathrm{~h}$ and the dried residues were weighed for the IVND. The concentrations of
VFA were determined by gas chromatography (Agilent Technologies, USA, Model GC6890) with a flame ionization detector and fused silica capillary column. The above in vitro procedure was performed in two runs. The three analytical replicates for each parameter (i.e., total gas, $\mathrm{CH}_{4}, \mathrm{CH}_{4}$ /total gas, IVDMD, rate of gas production) from each run were averaged and used as replicate in the statistical analysis.

\section{Statistic analysis}

The data were analyzed by analysis of variance using the general linear model procedure of SAS. Orthogonal polynomial contrasts were used to test for linear, quadratic and cubic effects of the different levels of CT. Significant differences were defined using $\mathrm{p} \leq 0.05$. The rate of gas production was analyzed using the non-linear procedure of SAS by fitting data of cumulative gas production to the exponential equation described above.

\section{RESULTS}

The concentration of CT in mangosteen-peel was estimated to be 0.154 (DM basis) while the molecular weight, defined as $M_{\mathrm{w}}$, was $2,081 \mathrm{Da}$ and $M_{n}$ was 1,133 . The $M_{\mathrm{w}}$ value was about twice the $M_{\mathrm{n}}$, thus, the calculated PDI $\left(M_{\mathrm{w}} / M_{\mathrm{n}}\right)$ was 1.84 . Protein binding affinity of the CT from mangosteen-peel was estimated to be 0.690 (Figure 1).

Although the rates of gas production $(c)$ were not different among treatments, ranging from 0.004 to 0.016 , total gas production $(24 \mathrm{~h})$ decreased linearly $(\mathrm{p}<0.01)$ with increased addition of CT. Similarly, addition of CT also resulted in a linear decrease $(\mathrm{p}<0.01)$ in $\mathrm{CH}_{4}, \mathrm{CO}_{2}$ productions and $\mathrm{CH}_{4}$ : total gas for the $\mathrm{CT}$ free control and the $30 \mathrm{mg}$ CT treatment group. However, addition of CT did not affect $\mathrm{H}_{2}$ production but_resulted in linear decrease $(\mathrm{p}<0.01)$ in IVDMD and IVND (Table 1).

Total VFA and concentration of acetic, propionic, butyric, isovaleric, and valeric acids decreased linearly with addition of CT (Table 2). Acetic acid concentration decreased by 0.177 from $35.01 \mathrm{mmol}$ in the CT-free control group to $28.83 \mathrm{mmol}$ for the $30 \mathrm{mg}$ CT treatment group, while those for propionic acid decreased by 0.208 from 7.87 to $6.23 \mathrm{mmol}$, respectively, for the control and $30 \mathrm{mg} \mathrm{CT}$ groups, thus resulting in a linear increase in the acetic: propionic ratio with addition of $\mathrm{CT}$.

\section{DISCUSSION}

The concentration of CT from mangosteen-peel determined in the present study was 0.154 . This value is consistent with those reported by Ngamsaeng et al. (2006) and Suchitra and Wanapat (2008) (0.168 and 0.156, respectively). Concentration of $\mathrm{CT}$ in different species of 


\section{BSA (mg)}

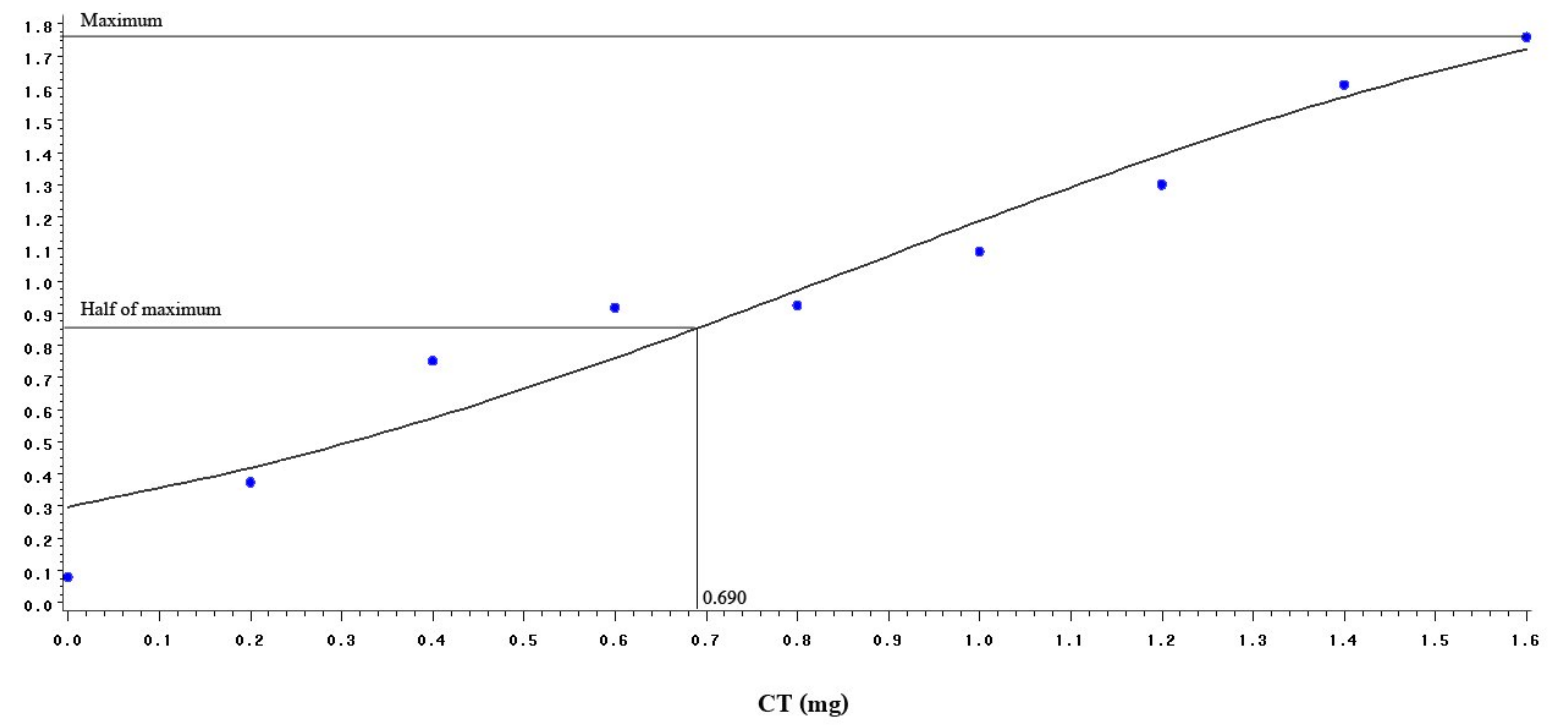

Figure 1. Protein binding affinity of condensed tannin from mangosteen peel as determined by the amount needed to bind half of the maximum bovine serum albumin (BSA) was 0.69 .

Leucaena, a widely used forage supplement for ruminant animals in the tropics and sub-tropics, was reported to range from very low to 0.310 (Castillo et al., 1997; McNeill et al., 1998). The relative concentration of CT is one important factor for tannin-protein interaction in a feed material
(Waterman and Mole, 1994), with the general rule that a feed ingredient with higher CT content has a stronger protein binding affinity which can prevent it being rapidly fermented in the rumen resulting in higher outflow of dietary protein into the small intestine.

Table 1. Effects of different levels of condensed tannin (CT) from mangosteen-peel on in vitro rumen fermentation parameters

\begin{tabular}{|c|c|c|c|c|c|c|c|c|}
\hline & \multicolumn{4}{|c|}{ CT (mg/500 mg DM) } & \multirow{2}{*}{ SEM } & \multicolumn{3}{|c|}{$\mathrm{p}$ value } \\
\hline & 0 & 10 & 20 & 30 & & $\mathrm{~L}$ & Q & $\mathrm{C}$ \\
\hline Total gas (mL/g DM) & 70.48 & 67.60 & 62.00 & 48.58 & 1.763 & 0.0006 & 0.1547 & 0.7483 \\
\hline $\mathrm{CH}_{4}(\mathrm{~mL} / \mathrm{g} \mathrm{DM})$ & 6.72 & 5.30 & 4.35 & 3.03 & 0.134 & $\leq 0.0001$ & 0.8621 & 0.4913 \\
\hline $\mathrm{CH}_{4} /$ total gas & 0.10 & 0.08 & 0.07 & 0.06 & 0.001 & $\leq 0.0001$ & 0.0111 & 0.2046 \\
\hline $\mathrm{H}_{2}(\mathrm{~mL} / \mathrm{g} \mathrm{DM})$ & 0.02 & 0.02 & 0.03 & 0.04 & 0.004 & 0.0713 & 1.0000 & 1.0000 \\
\hline $\mathrm{CO}_{2}(\mathrm{~mL} / \mathrm{g} \mathrm{DM})$ & 5.82 & 5.67 & 5.12 & 3.44 & 0.179 & 0.0004 & 0.0546 & 0.6593 \\
\hline IVDMD & 0.14 & 0.10 & 0.08 & 0.06 & 0.005 & $\leq 0.0001$ & 0.2814 & 0.4802 \\
\hline IVND & 0.43 & 0.38 & 0.34 & 0.31 & 0.005 & $\leq 0.0001$ & 0.4954 & 0.7940 \\
\hline$c\left(h^{-1}\right)$ & 0.016 & 0.004 & 0.008 & 0.010 & 0.0034 & 0.6653 & 0.2746 & 0.5709 \\
\hline
\end{tabular}

DM, dry matter; SEM, standard error of the mean; L, linear effect; Q, quadratic effect; C, cubic effect; IVDMD, in vitro DM degradability; IVND, in vitro nitrogen degradability; $\mathrm{c}$, the rate of gas production $\left(\mathrm{h}^{-1}\right)$.

Table 2 Effects of different levels of condensed tannins (CT) from mangosteen-peel on in vitro volatile fatty acids (VFA) production

\begin{tabular}{|c|c|c|c|c|c|c|c|c|}
\hline & \multicolumn{4}{|c|}{ CT (mg/500 mg DM) } & \multirow{2}{*}{ SEM } & \multicolumn{3}{|c|}{$\mathrm{p}$ value } \\
\hline & 0 & 10 & 20 & 30 & & $\mathrm{~L}$ & $\mathrm{Q}$ & $\mathrm{C}$ \\
\hline Acetic acid & 35.01 & 33.40 & 30.79 & 28.83 & 0.581 & 0.0016 & 0.8846 & 0.7566 \\
\hline Propionic acid & 7.87 & 7.29 & 6.79 & 6.23 & 0.141 & 0.0010 & 0.9742 & 0.9003 \\
\hline Butyric acid & 3.44 & 3.11 & 3.02 & 2.77 & 0.096 & 0.0304 & 0.8267 & 0.6608 \\
\hline Acetic:propionate & 4.45 & 4.59 & 4.53 & 4.64 & 0.025 & 0.0491 & 0.1100 & 2.3700 \\
\hline Isobutyric acid & 0.48 & 0.66 & 0.38 & 0.37 & 0.065 & 0.3143 & 0.4744 & 0.2370 \\
\hline Isovaleric acid & 1.10 & 0.92 & 0.83 & 0.82 & 0.041 & 0.0272 & 0.3189 & 0.9534 \\
\hline Valeric acid & 0.46 & 0.40 & 0.38 & 0.37 & 0.018 & 0.0995 & 0.5885 & 0.9352 \\
\hline Total VFA & 48.36 & 45.78 & 42.19 & 39.40 & 0.883 & 0.003 & 0.884 & 0.922 \\
\hline
\end{tabular}

DM, dry matter; SEM, standard error of the mean; L, linear effect; Q, quadratic effect; C, cubic effect. 
However, several researchers examined the effect of molecular weight of CT on protein binding affinity (Aerts et al., 1999) and in vitro gas including $\mathrm{CH}_{4}$ production (Huang et al., 2010) and reported that besides its concentration, CT of larger molecular weight has stronger influence on the above mentioned parameters. In general, molecular weight of polyphenol in plants ranged from 100 to $10,000 \mathrm{Da}$ (Yanagita et al., 1999). Among fruits, it was reported CT from apple juice ranged from 1,754 to 2,907 Da (Shoji et al., 2006) and from 465 to 2,194 Da for grape seed (Yang and Chien, 2000). The molecular weight of CT from mongosteen-peel estimated in this study (2,081 Da) falls within the published range of the various plant materials. However, the molecular weight of the CT from mangosteen-peel is about 0.25 lower than those reported by Huang et al. (2010) for Malaysian Leucaena leucocephala (2,737 Da) and its hybrid (62-2-8 Leucaena leucocephala hybrid-Bahru; 2,871 Da). The lower molecular weight of CT from mangosteen-peel compared to the Leucaena forages could explain the lower protein binding affinity of the former $(b=0.690)$ as compared to the Leucaena forages ( $b=0.305$ to 0.420 ) previously reported (Huang et al., 2010) using similar protocol.

Total gas production declined by the fraction of 0.041 , 0.121 , and 0.311 , respectively, with the 10,20 , and $30 \mathrm{mg}$ CT treatments as compared to the control. The above results suggested that CT from mangosteen-peel has a weaker inhibition effect on fermentation rate than those reported for Leucaena leucocephala hybrid (0.197 and 0.336, respectively for 10 and $20 \mathrm{mg}$ CT treatments) by Huang et al. (2010). Similarly, addition of CT also resulted in linear decrease $(\mathrm{p}<0.01)$ in $\mathrm{CH}_{4}$ production by fractions of 0.211 , 0.353 , and 0.549 , respectively, with addition of 10,20 , and $30 \mathrm{mg}$ CT compared to the control $(\mathrm{p}<0.05)$. Although the effect of tannins from mangosteen-peel on $\mathrm{CH}_{4}$ production has been reported by several authors (Poungchompu et al., 2009; Pilajun and Wanapat, 2011; Thanh et al., 2012), they used whole mangosteen-peel powder, which reportedly containing tannins, rather than pure $\mathrm{CT}$ as the $\mathrm{CH}_{4}$ inhibitor in this study. The present results indicate that the inhibitory effect of CT from mangosteen-peel (based on similar CT dosage) on $\mathrm{CH}_{4}$ production is lower than that of $\mathrm{CT}$ from Leucaena reported by Huang et al. (2010). The latter examined the additions of $10,15,20$, and $25 \mathrm{mg} \mathrm{CT} / 500$ $\mathrm{mg}$ DM, reported reductions of 0.285 for $10 \mathrm{mg} \mathrm{CT} / 500 \mathrm{mg}$ DM and 0.451 for $20 \mathrm{mg} \mathrm{CT} / 500 \mathrm{mg} \mathrm{DM}$ groups. The lower inhibitory effect of CT from mangosteen-peel as compared to that from Leucaena on $\mathrm{CH}_{4}$ production could be explained by the smaller molecular weight of the former or different molecular structure of the two sources (Huang et al., 2011a).

The significantly lower $\mathrm{CH}_{4}$ :total gas production ratios between the CT supplemented groups compared to the control implies that $\mathrm{CT}$ had direct effect on reduction of $\mathrm{CH}_{4}$ and the reduction in $\mathrm{CH}_{4}$ was not due to the lower total gas production. This observation suggests that CT of mangosteen-peel has stronger effect on $\mathrm{CH}_{4}$ than overall fermentation rate. Although the present study did not examine changes in the microbial population, including the methanogens, to explain for the effect of CT from mangosteen-peel on $\mathrm{CH}_{4}$ production, previous study conducted in our laboratory (Tan et al., 2011) suggested CT from Leucaena suppresses $\mathrm{CH}_{4}$ production by reducing methanogens and protozoa populations. Interesting, Pilajun and Wanapat (2011) reported that the effect of mangosteenpeel on $\mathrm{CH}_{4}$ reduction was lower than that of coconut oil or coconut oil-mangosteen-peel mixture. The authors also reported no differences in methanogens population except minor differences in the methanogen diversity among treatments.

The present results clearly suggest that CT from mangosteen-peel had strong negative effect on IVDMD, nearly by 0.300 even at the lowest inclusion rate of 10 $\mathrm{mg} / 500 \mathrm{mg}$ DM as compared to the control. In agreement with our results, Tiemann et al. (2008b) reported that although inclusion of tannin-rich plants reduced $\mathrm{CH}_{4}$ emission, the reduction in $\mathrm{CH}_{4}$ seems to have been mostly the result of a reduced organic matter and fiber digestion.

The primary objective of many studies (Osborne and McNeill, 2001; Kariuki and Norton, 2008) on CT focused on the capability of the CT to bind protein to protect it from microbial fermentation for more efficient utilization of quality dietary protein in the small intestine in ruminant animals. The approximately 0.120 to 0.280 reduction in IVND due to addition of CT recorded in the present study thus suggests that a significant amount of protein could be protected from being fermented in the rumen which could eventually be hydrolyzed and absorbed in the small intestine for the use by the host animals. However, further studies are needed to overcome the strong negative effect of CT from mangosteen-peel on IVDMD if mangosteen-peel is to be used as source of slowly fermentable dietary protein or $\mathrm{CH}_{4}$ inhibitor in ruminants.

Just like total gas production, in vitro VFA production data provides a useful assessment of the extent of feed, particularly carbohydrate, fermentation in the rumen. Total VFA production decreased linearly from 48.36 (control) to between 45.78 to $39.40 \mathrm{mmol}$, equivalent to between 0.053 to 0.185 reduction from 10 to $30 \mathrm{mg}$ treatment groups. This was expected as addition of CT has resulted in significant negative effect on IVDMD, an indication of its negative effect of microbial activity. However, the ratio of $\mathrm{CH}_{4}$ per unit VFA production (the latter indicating fermentation rate) reduced from for $13.89 \mathrm{~mL} / \mathrm{g} \mathrm{DM}$ for the control to 11.58 , 10.41 , and $7.69 \mathrm{~mL} / \mathrm{g}$ DM, respectively for 10,20 , and 30 $\mathrm{mg}$ treatment groups. The above result, in agreement with 
that of $\mathrm{CH}_{4}$ per unit total gas production (see earlier discussion) suggests that $\mathrm{CT}$ from mangosteen-peel has stronger inhibition effect on $\mathrm{CH}_{4}$ production in relation to total gas and total VFA productions. Addition of CT from mangosteen-peel reduced the concentrations of acetic acid, propionic acid, butyric acid, isovaleric acid and increased the acetic:propionic ratio. In contrast, Poungchompu et al. (2009) reported supplementation of 0.121 of a mixture of soapberry fruit and mangosteen-peel increased total VFA and propionate concentration but that of acetate decreased. The inconsistent results between the two studies could be because the supplement used in the latter study contained a mixture of saponins and tannins.

\section{CONCLUSION}

Because of the relatively high $\mathrm{CP}$ content and the presence of tannins in the mangosteen-peel, there is an increasing interest to use this byproduct from the fruitprocessing industry as a source of non-degradable protein and $\mathrm{CH}_{4}$ mitigating agent in ruminants. To the best of our knowledge, the present study is the first to purify the CT from mangosteen-peel and determine its molecular weight and further examine its efficacy to bind protein and to inhibit $\mathrm{CH}_{4}$ production in vitro. Since CT from mangosteenpeel has strong negative effects on IVDMD, the use of this material as feed ingredient in ruminant production requires further investigations including in vivo feeding trials.

\section{ACKNOWLEDGMENTS}

The senior author wishes to thank the University Putra Malaysia, Suranaree University of Technology for the use of research facilities for this study.

\section{REFERENCES}

Aerts, R. J., W. C. McNabb, A. Molan, A. Brand, T. N. Barry, and J. S. Peters. 1999. Condensed tannins from Lotus corniculatus and Lotus pedunculatus exert different effects on the in vitro rumen degradation of ribulose-1,5-bisphosphate carboxylase/ oxygenase (Rubisco) protein. J. Sci. Food Agric. 79:79-85.

Castillo, A. C., O. C. Cuyugan, S. Fogarty, and H. M. Shelton. 1997. Growth, psyllid resistance and forage quality of Leucaena leucocephala $\times$ L. pallid. Trop. Grassl. 31:188-200.

Frutos, P., G. Hervás, F. J. Giráldez, and A. R. Mantecón. 2004. Review. Tannins and ruminant nutrition. Spanish J. Agric. Res. 2:191-202.

Huang, X. D., J. B. Liang, H. Y. Tan, R. Yahya, B. Khamseekhiew, and Y. W. Ho. 2010. Molecular weight and protein binding affinity of Leucaena condensed tannins and their effects on in vitro fermentation parameters. Anim. Feed Sci. Technol. 159: 81-87.

Huang, X. D., J. B. Liang, H. Y. Tan, R. Yahya, and Y. W. Ho. 2011a. Effects of Leucaena condensed tannins of differing molecular weights on in vitro $\mathrm{CH}_{4}$ production. Anim. Feed Sci. Technol. 166-167:373-376.

Huang, X. D., J. B. Liang, H. Y. Tan, R. Yahya, R. J. Long, and Y. W. Ho. 2011b. Protein-binding affinity of Leucaena condensed tannins of differing molecular weights. J. Agric. Food Chem. 59:10677-10682.

Jones, R. J., J. H. F. Meyer, M. Bechaz, and M. A. Stoltz. 2000. An approach to screening potential pasture species for condensed tannin activity. Anim. Feed Sci. Technol. 85:269-277.

Kariuki, I. W. and B. W. Norton. 2008. The digestion of dietary protein bound by condensed tannins in the gastro-intestinal tract of sheep. Anim. Feed Sci. Technol. 142(3-4):197-209.

Lascano, C., P. Avila, and J. Stewart. 2003. Intake, digestibility and nitrogen utilization by sheep fed with provenances of Calliandra calothyrsus Meissner with different tannin structure. Arch. Latinoam. Prod. Anim. 11:21-28.

Makkar, H. P. S., M. Blümmel, and K. Becker. 1997. In vitro rumen apparent and true digestibilities of tannin-rich forages. Anim. Feed Sci. Technol. 67:245-251.

Makkar, H. P. S., P. K. Dawra, and B. Singh. 1987. Protein precipitation assay for quantitation of tannins: Determination of protein in tannin-protein complex. Anal. Biochem. 166: 435-439.

McAllister, T. A., H. D. Bae, G. A. Jones, and K. J. Cheng. 1994. Microbial attachment and feed digestion in the rumen. J. Anim. Sci. 72:3004-3018.

McNeil, D. M., N. Osborne, M. K. Komolong, and D. Nankervis. 1998. Condensed tannins in the genus Leucaena and their nutritional significance for ruminants. ACIAR proceedings No. 86, Leucaena-Adaptation, Quality and Farming System, Hanoi Vietnam. pp. 205-214.

Menke, K. H. and H. Steingass. 1988. Estimation of the energetic feed value obtained by chemical analysis and in vitro gas production using rumen fluid. Anim. Res. Dev. 28:55.

Ngamsaeng, A., M. Wanapat, and S. Khampa. 2006. Effects of mangosteen peel (Garcinia mangostana) supplementation on rumen ecology, microbial protein synthesis, digestibility and voluntary feed intake in cattle. Pakistan J. Nutr. 5:445-452.

Ørskov, E. R. and I. McDonald. 1979. The estimation of protein degradability in the rumen from incubation measurements weighted according to rate of passage. J. Agric. Sci. 92:499503.

Pilajun, R. and M. Wanapat. 2011. Methane production and methanogen population in rumen liquor of swamp buffalo as influenced by coconut oil and mangosteen peel powder supplementation. J. Anim. Vet. Adv. 10:2523-2527.

Poungchompu, O., M. Wanapat, C. Wachirapakorn, S. Wanapat, and A. Cherdthong. 2009. Manipulation of ruminal fermentation and methane production by dietary saponins and tannins from mangosteen peel and soapberry fruit. Arch. Anim. Nutr. 63:389-400.

Sahoo, A., B. Singh, and T. K. Bhat. 2010. Effect of tannins on in vitro ruminal protein degradability of various tree forages. Livest. Res. Rural Dev. 22(7).

Shoji, T., S. Masumoto, N. Moriichi, T. Kanda, and Y. Ohtake. 2006. Apple (Malus pumila) procyanidins fractionated according to the degree of polymerization using normal-phase chromatography and characterized by HPLC-ESI/MS and MALDI-TOF/MS. J. Chromatogr. A 1102:206-213. 
Suchitra, K. and M. Wanapat. 2008. Effects of mangosteen (Garcinia mangostana) peel and sunflower and coconut oil supplementation on rumen fermentation, milk yield and milk composition in lactating dairy cows. Livest. Res. Rural Dev. Volume 20. http://www.lrrd.org/lrrd20/supplement/such2.htm Accessed December 20, 2013.

Tan, H. Y., C. C. Sieo, N. Abdullah, J. B. Liang, X. D. Huang, and Y. W. Ho. 2011. Effects of condensed tannins from Leucaena on methane production, rumen fermentation and populations of methanogens and protozoa in vitro. Anim. Feed Sc. Technol. 169:185-193.

Terrill, T. H., A. M. Rowan, G. B. Douglas, and T. N. Barry. 1992. Determination of extractable and bound condensed tannin concentrations in forage plants, protein concentrate meals and cereal grains. J. Sci. Food Agric. 58:321-329.

Terrill, T. H., W. R. Windham, J. J. Evans, and C. S. Hoveland. 1990. Condensed tannin concentration in Sericea lespedeza as influenced by preservation method. Crop Sci. 30:219-224.

Tilley, J. M. A. and R. A. Terry. 1963. A two-stage technique for the in vitro digestion of forage crops. Grass Forage Sci. 18:104-111.

Tiemann, T. T., C. E. Lascano, M. Kreuzer, and H. D. Hess. 2008a. The ruminal degradability of fibre explains part of the low nutritional value and reduced methanogenesis in highly tanniniferous tropical legumes. J. Sci. Food Agric. 88:17941803.
Tiemann, T. T., C. E. Lascano, H. R. Wettstein, A. C. Mayer, M. Kreuzer, and H. D. Hess. 2008b. Effect of the tropical tanninrich shrub legumes Calliandra calothyrsus and Flemingia macrophylla on methane emission and nitrogen and energy balance in growing lambs. Animal 2:790-799.

Thanh, V. D., N. V. Thu, and T. R. Preston. 2012. Effect of potassium nitrate or urea as NPN source and levels of mangosteen peel on in vitro gas and methane production using molasses, Operculina turperthum and Brachiaria mutica as substrate. Livest. Res. Rural Dev. Vol 24. Article \#63. http://www.lrrd.org/lrrd24/4/thanh24063.htm Accessed December 20, 2013.

Williams, V. M., L. J. Porter, and R. W. Hemingway. 1983. Molecular weight profiles of proanthocyanidin polymers. Phytochemistry 22:569-572.

Yanagida, A., T. Kanada, T. Shoji, M. Ohnishi-Kameyama, and T. Nagata. 1999. Fractionation of apple procyanidins by sizeexclusion chromatography. J. Chromatogr. A. 855:181-190.

Yang, Y. and M. Chien. 2000. Characterization of grape procyanidins using high-performance liquid chromatography/mass spectrometry and matrix-assisted laser desorption/ionization time-of-flight mass spectrometry. J. Agric. Feed Chem. 48:3990-3996. 